Innlegg på inntil 400 ord lastes opp i http://mc.manuscriptcentral.com/tidsskriftet.

Redaksjonen forbeholder seg retten til å foreta redaksjonelle endringer.

Forfattere av vitenskapelige artikler har automatisk tilsvarsrett (jf. Vancouver-gruppens regler).

\section{Til å misforstå om pregabalinmisbruk}

I Tidsskriftet nr. 3/2011 bruker Landmark og medarbeidere tall fra Reseptregisteret for å studere omfang av pregabalinmisbruk i Norge i 2008-09 (1). Statistikken er interessant, men presentasjonen gir rom for misforståelser. De fant at $0,01 \%$ av pregabalinbrukerne fikk forskrevet mer enn ti ganger den definerte døgndosen (DDD), og kommenterer dette med at $«(\ldots)$ [disse] ble definert som storforbrukere og potensielle misbrukere.» Setningen kan leses som at pregabalinmisbruk er svært sjeldent forekommende, med høyst én misbrukende per 10000 pasienter, med andre ord høyst to tilfeller i Norge. Omtalen av de $0,6 \%$ av pasientene som brukte 5-10 ganger DDD er også forvirrende. Her står det ingenting om misbruk. Først i siste avsnitt kan man lese at døgndosen kan «være opptil fem ganger normaldoseringen uten at dette kan defineres som misbruk». Denne setningen må leseren selv vri om på for å oppfatte hva det innebærer å bruke mer enn fem ganger DDD, hvilket $0,6 \%$ av pasientene altså gjør.

Det er viktig at ikke Landmark og medarbeideres innlegg feilaktig blir brukt som et argument mot at pregabalin misbrukes. Tallene fra Reseptregisteret bør heller oppsummeres som følger: Drøyt én av 200 pasienter får forskrevet pregabalindoser som er tydelig assosiert med misbruk. I tillegg forekommer misbruk også blant pasienter som får forskrevet pregabalin i lavere doser (2), og dessuten - som vi ser ved rusmiddeltesting - blant mange som ikke får pregabalin forskrevet i det hele tatt.

Vi vet fra andre legemiddelgrupper at kartlegging av misbrukspotensial kan ta lang tid. Dette - sammen med de kasuistikker som finnes, og som stadig tilkommer (2-5) - bør etter vårt syn mane til aktsomhet når det gjelder forskrivning av pregabalin.

\section{Andreas Austgulen Westin \\ Arne Helland \\ St. Olavs hospital \\ Elin Johanne Hansteen Strøm \\ Lade behandlingssenter

\footnotetext{
Litteratur

1. Landmark CJ, Fossmark H, Larsson PG et al. Reseptregisteret og misbruk av pregabalin. Tidsskr Nor Lægeforen 2011; 131: 223.

2. Westin AA, Strøm EJ. Ja, pregabalin kan mis-
} brukes! Tidsskr Nor Lægeforen 2010; 130: 2108.}

3. Bramness JG. Misbruk av pregabalin. Tidsskr Nor Legeforen 2010; 130: 1703-4

4. Filipetto FA, Zipp CP, Coren JS. Potential for pregabalin abuse or diversion after past drug-seeking behavior. J Am Osteopath Assoc 2010; 110: 605-7. 5. Schifano F, D'Offizi S, Piccione M et al. Is there a recreational misuse potential for pregabalin? Analysis of anecdotal online reports in comparison with related gabapentin and clonazepam data. Psychother Psychosom 2011; 80: 118-22.

\section{Epikrise er en kvalitetsindikator}

Jeg kunne ikke sett meg mer enig med Gunnar Andersen om epikriser som gir læring i Tidsskriftet nr. 3/2011 (1). Begrepet epikrise kommer fra gresk $\varepsilon \pi \imath \kappa \rho \imath \sigma \iota$ fra $\varepsilon \pi \imath$ «etter» og $\kappa \rho \imath \sigma \imath \varsigma$ «vurdering». Den skal bestå av en oppsummering av sykdomsforløpet, interpretasjon av symptomene og funn samt overveielsene behandleren gjorde. Så skal den gjøre rede for terapien. I den faglige diskurs ligger den største læringseffekten.

Epikrisens rolle er imidlertid blitt utvannet i den senere tid. Kortere liggetid fører til økt antall epikriser med komplekse undersøkelsesfunn. I en travel hverdag kan det bli vanskelig å få laget den når pasienten skrives ut. Epikriseskrivingen blir utsatt, og ikke-dokumentert informasjon går tapt. Skriving av epikrise anses som mindre betydningsfullt enn andre legegjerninger som f.eks. operasjon og overlates derfor ofte til yngre leger. Bare epikrisen sendes ut, anses det som godt nok. Spesialistene er travelt opptatt og involverer seg sjelden i tilbakemeldingen. Læringseffekten går tapt - også for dem som behandlet pasienten under oppholdet.

Epikrisen utløser DRG-kodene og er direkte forbundet med helseforetakets inntekter. Millioner av kroner går tapt fordi sykdomsforløpet ikke gjenspeiles i en fullstendig oppsummering. Tid til utsendelse av epikrisen er vedtatt som kvalitetsindikator av helsemyndighetene (2). Sykehusadministrasjonene er nok derfor mer opptatt av at fristen for utsendelsen blir overholdt enn av det faglige innholdet. Det gjør et viktig instrument $i$ kvalitetssikring og inntektssikring til en salderingspost.

Legene må bruke epikrisen til det den opprinnelig er tiltenk: som et instrument til å kommunisere med involvert helsepersonell slik at pasientens oppfølging og behandling blir ivaretatt på en trygg måte. Informasjon om funn og sykdomsutvikling under syke- husoppholdet gjør det lett for oppfølgende helsepersonell å gi pasient og pårørende informasjon de ikke hadde fătt med seg under oppholdet. Pasientsikkerhet og oppfølging fortjener at ressursbruk til epikriseskriving prioriteres. Merkantile aspekter og styringsindikatorer bør komme i annen rekke!

\section{Winfried Rüger \\ Seksjon urologi \\ Helse Fonna \\ Haugesund
Litteratur
1. Andersen G. Epikriser gir læring. Tidsskr Nor Legeforen 2011: 131: 226
2. Helsedirektoratet. Indikator: Epikrisetid. www. helsedirektoratet.no/vp/multimedia/archive/ 00105/N-002_somatikk_ande_105769a.pdf (8.3.2011).

\section{Skiencefali og andre «fali'e» tilstander}

Nevrolog Karl Otto Nakken hadde i Tidsskriftet nr. 4/2011 en særdeles humoristisk artikkel om det å ha ski på hjernen (1). Til alt overmål var den timet slik at vi kunne lese den mens VM på ski ble arrangert i Oslo. En god latter forlenger som kjent livet, og Karl Otto Nakken fortjener all mulig takk!

Karl Otto Nakken var i sine yngre dager en meget dyktig orienteringsløper, og for alt jeg vet, er han det kanskje ennå. Da er det mulig han har pådratt seg en såkalt okartose med tilhørende kompassitt. Denne tilstanden påvirker stedsansen og de såkalte gittercellene i hjernen på en positiv måte.

Gittercellene er ganske nylig blitt oppdaget av professorene E. Moser og M-B. Moser ved Norges teknisk-naturvitenskapelige universitet. De får i år Louis-Jeantetprisen for sin forskning (2). Moser-ekteparet fortsetter jakten på stedsansen og skal undersøke hvordan gittercellene oppfører seg bl.a. i hippocampus.

Kan vi ane konturene av et samarbeid mellom Norges teknisk-naturvitenskapelige universitet og nevrologisk avdeling, Rikshospitalet?

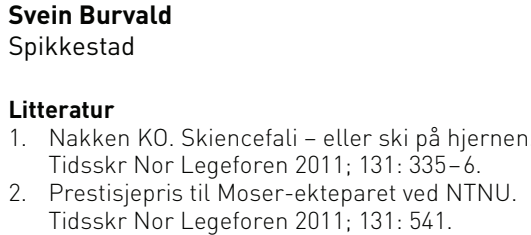

